\title{
Effect of the Soil pH on the Alkaloid Content of Lupinus angustifolius
}

\author{
Gisela Jansen, Hans-Ulrich Jürgens, Edgar Schliephake, and Frank Ordon \\ Institute for Resistance Research and Stress Tolerance, Julius Kühn-Institut (JKI), Federal Research Centre for Cultivated Plants, \\ 18190 Sanitz, Germany \\ Correspondence should be addressed to Gisela Jansen, gisela.jansen@jki.bund.de
}

Received 4 June 2012; Accepted 26 October 2012

Academic Editor: O. Mario Aguilar

Copyright (๑) 2012 Gisela Jansen et al. This is an open access article distributed under the Creative Commons Attribution License, which permits unrestricted use, distribution, and reproduction in any medium, provided the original work is properly cited.

Field studies were conducted in growing seasons 2004, 2005, and 2010 to investigate the effect of different soil pH values on the alkaloid content in seeds of Lupinus angustifolius. Two-year experiments with eleven cultivars were carried out in acid soils with an average of $\mathrm{pH}=5.8$ (Mecklenburg-Western Pomerania) and on calcareous soils with an average $\mathrm{pH}$ of 7.1 (Bavaria), respectively. In addition, in 2010, eight cultivars were grown in field experiments in soils with $\mathrm{pH}$ values varying between $\mathrm{pH}=5.3$ and $\mathrm{pH}=6.7$. In all experiments conducted on soils with a higher $\mathrm{pH}(\mathrm{pH}=6.7$ and $\mathrm{pH}=7.1)$, a significantly lower alkaloid content was detected in all Lupinus angustifolius cultivars than on soils with a lower $\mathrm{pH}(\mathrm{pH}=5.3$ and $\mathrm{pH}=5.8)$. Results clearly show that the alkaloid content is significantly influenced by the soil $\mathrm{pH}$ but genotypic differences regarding the reaction to different $\mathrm{pH}$ values in the soil were observed.

\section{Introduction}

Lupins as protein crops can be used in many ways. They are grown for green manure, for animal feed, or for human nutrition. Unlimited feeding of bitter seeds led to the disease "lupinose" in former times. It was caused by the alkaloids contained in bitter lupins [1]. Only breeding of the socalled sweet lupins [2] facilitates the use of lupins to a greater extent in animal feed and for human nutrition. But besides genetics the alkaloid content in sweet lupins, for example, Lupinus angustifolius, is influenced by different environmental factors. Apart from drought, heat, and nutrient deficiencies, plants are largely affected by the soil $\mathrm{pH}$ [3]. Lupin species are differing concerning their demands for optimal growth, but in general commercial cultivars of lupins grow poorly on alkaline or neutral soils [4]. In general blue lupins (Lupinus angustifolius) and especially yellow lupins (Lupinus luteus) are less sensitive to calcareous soils than white lupins (Lupinus albus) [5, 6]. The soil pH considerably influences yield and protein content of Lupinus angustifolius $[7,8]$, that is, the higher the soil $\mathrm{pH}$ the lower the kernel yield and protein content. Besides this, the $\mathrm{pH}$ value has an impact on the production of secondary metabolites [911], for example, out of many soil parameters analysed, the highest correlation of the production of the glycoside salidroside in Rhodiola sachalinensis was observed to the soil pH [9]. Similar results were obtained for the alkaloid production, for example, when the $\mathrm{pH}$ value in cell culture media of Lupinus polyphyllus decreased from $\mathrm{pH}=5.5$ to $\mathrm{pH}$ $=3.5$, the alkaloid production increased [12].

The objective of our field studies was to assess the influence of the soil $\mathrm{pH}$ on the alkaloid content of narrowleafed lupin cultivars (Lupinus angustifolius).

\section{Materials and Methods}

2.1. Field Trials. Seeds of Lupinus angustifolius cultivars Borlana, Borweta, Bordako, Boruta, Borlu, Bora, Boregine, Boltensia, Bolivio, Vitabor, and Haags Blaue were supplied by the seed company Saatzucht Steinach (Bornhof, Germany). The variety Sonet was provided by Kruse Saatzucht (Münster, Germany).

In 2004 and in 2005, field experiments with 11 cultivars of Lupinus angustifolius (except Haags Blaue) were carried out under organic farming conditions in Bogen (Bavaria, northern latitude: 48.912925 , eastern longitude: 12.692792) and in Gross Luesewitz (Mecklenburg-Western Pomerania, 
TABLE 1: Characteristic of locations.

\begin{tabular}{|c|c|c|c|c|}
\hline & \multicolumn{2}{|c|}{ Mecklenburg-Western Pomerania } & \multicolumn{2}{|c|}{ Bavaria } \\
\hline & Gross Luesewitz & Bornhof & Bogen & Gründl \\
\hline Soil type & Loamy sand & Sand & Sandy clay loam & Sandy loam \\
\hline $\mathrm{pH}$ value & 5.8 & 5.3 & 7.2 & 6.7 \\
\hline Mean annual rainfall (mm) & 620 & 558 & 803 & 822 \\
\hline Mean annual temperature $\left({ }^{\circ} \mathrm{C}\right)$ & 8.2 & 8.2 & 7.7 & 8.6 \\
\hline
\end{tabular}

Source: $[8,13]$.

TABLE 2: Content of alkaloids in different cultivars of Lupinus angustifolius at different locations (2004 and 2005).

\begin{tabular}{|c|c|c|c|c|c|c|c|c|c|}
\hline \multirow{2}{*}{ Genotype } & \multirow{2}{*}{ Year } & \multicolumn{2}{|c|}{ 13-Hydroxylupanine } & \multicolumn{2}{|c|}{ Angustifoline } & \multicolumn{2}{|c|}{ Isolupanine } & \multicolumn{2}{|c|}{ Lupanine } \\
\hline & & Bo & GL & Bo & GL & Bo & GL & Bo & GL \\
\hline \multirow{3}{*}{ Bolivio } & 2004 & 45.5 & 215.5 & 20.8 & 102.8 & 7.0 & 23.7 & 16.8 & 179.2 \\
\hline & 2005 & 52.2 & 157.8 & 41.8 & 87.3 & 10.2 & 26.6 & 6.6 & 204.7 \\
\hline & Mean & 48.9 & 186.7 & 31.3 & 95.1 & 8.6 & 25.2 & 11.7 & 192.0 \\
\hline \multirow{3}{*}{ Boltensia } & 2004 & 2.4 & 73 & 2.3 & 52.1 & 2.3 & 11.3 & 7.5 & 136.5 \\
\hline & 2005 & 1.8 & 58.1 & 1.5 & 50.5 & 0.0 & 16.8 & 1.2 & 216.8 \\
\hline & Mean & 2.1 & 65.6 & 1.9 & 51.3 & 1.2 & 14.1 & 4.4 & 176.7 \\
\hline \multirow{3}{*}{ Bora } & 2004 & 15.5 & 119.9 & 13.3 & 78.3 & 6.8 & 24.2 & 27.7 & 199.1 \\
\hline & 2005 & 2.1 & 94.3 & 0.6 & 72.1 & 1.0 & 34.4 & 4.5 & 293.8 \\
\hline & Mean & 8.8 & 107.1 & 7.0 & 75.2 & 3.9 & 29.3 & 16.1 & 246.5 \\
\hline \multirow{3}{*}{ Bordako } & 2004 & 13.8 & 135.2 & 9.3 & 98.7 & 3.6 & 17.5 & 10.5 & 231.9 \\
\hline & 2005 & 4.9 & 80.1 & 4.6 & 80.7 & 1.4 & 26.8 & 2.6 & 340.8 \\
\hline & Mean & 9.4 & 107.7 & 7.0 & 89.7 & 2.5 & 22.2 & 6.6 & 286.4 \\
\hline \multirow{3}{*}{ Boregine } & 2004 & 12.7 & 67.6 & 7.4 & 46.3 & 4.6 & 18.8 & 10.5 & 113.6 \\
\hline & 2005 & 1.8 & 75.5 & 0.8 & 66.7 & 0.5 & 33.6 & 0.3 & 245.7 \\
\hline & Mean & 7.3 & 71.6 & 4.1 & 56.5 & 2.6 & 26.2 & 5.4 & 179.7 \\
\hline \multirow{3}{*}{ Borlana } & 2004 & 5.0 & 67.4 & 2.8 & 49.6 & 1.9 & 11.1 & 4.1 & 103.9 \\
\hline & 2005 & 5.1 & 43.7 & 5.5 & 41.1 & 1.1 & 14.1 & 0.9 & 171.9 \\
\hline & Mean & 5.1 & 55.6 & 4.2 & 45.4 & 1.5 & 12.6 & 2.5 & 137.9 \\
\hline \multirow{3}{*}{ Borlu } & 2004 & 12.6 & 118.6 & 5.7 & 79.5 & 3.3 & 18.8 & 9.6 & 151.2 \\
\hline & 2005 & 3.8 & 36.4 & 5.3 & 31.6 & 1.5 & 11.2 & 5.5 & 106.3 \\
\hline & Mean & 8.2 & 77.5 & 5.5 & 55.6 & 2.4 & 15.0 & 7.6 & 128.8 \\
\hline \multirow{3}{*}{ Boruta } & 2004 & 18.7 & 53.3 & 8.3 & 31.0 & 3.3 & 6.9 & 14.8 & 82.0 \\
\hline & 2005 & 2.7 & 34.7 & 0.5 & 32.0 & 0.0 & 7.2 & 2.4 & 115.0 \\
\hline & Mean & 10.7 & 44.0 & 4.4 & 31.5 & 1.7 & 7.1 & 8.6 & 98.5 \\
\hline \multirow{3}{*}{ Borweta } & 2004 & 11.2 & 119.2 & 6.4 & 87.0 & 3.0 & 12.4 & 17.3 & 167.4 \\
\hline & 2005 & 5.0 & 19.5 & 2.9 & 23.9 & 0.0 & 8.2 & 4.2 & 136.7 \\
\hline & Mean & 8.1 & 69.4 & 4.7 & 55.5 & 1.5 & 10.3 & 10.8 & 152.1 \\
\hline \multirow{3}{*}{ Sonet } & 2004 & 32.7 & 135.6 & 22.7 & 96.1 & 4.9 & 14.8 & 32.2 & 215.3 \\
\hline & 2005 & 35.7 & 89.8 & 36.8 & 98.1 & 3.7 & 15.1 & 55.4 & 364.0 \\
\hline & Mean & 34.2 & 112.7 & 29.8 & 97.1 & 4.3 & 15.0 & 43.8 & 289.7 \\
\hline \multirow{3}{*}{ Vitabor } & 2004 & 4.5 & 19.9 & 2.0 & 11.3 & 1.7 & 3.4 & 3.0 & 25.7 \\
\hline & 2005 & 2.2 & 14.7 & 0.7 & 10.1 & 0.0 & 3.1 & 0.6 & 36.9 \\
\hline & Mean & 3.4 & 17.3 & 1.4 & 10.7 & 0.9 & 3.3 & 1.8 & 31.3 \\
\hline
\end{tabular}

BO: Bogen, GL: Gross Luesewitz. 
TABLE 3: Mean content $( \pm S D)$ of alkaloids in different cultivars of Lupinus angustifolius at different locations (2004 and 2005).

\begin{tabular}{lcccc}
\hline Alkaloid & \multicolumn{2}{c}{ Bogen } & & \multicolumn{2}{c}{ Gross Luesewitz } \\
\hline 13-Hydroxylupanine & $13.3 \pm 14.9$ & a & $83.2 \pm 50.5$ & $\mathrm{~b}$ \\
Angustifoline & $9.2 \pm 11.5$ & $\mathrm{a}$ & $60.3 \pm 29.5$ & $\mathrm{~b}$ \\
Isolupanine & $2.8 \pm 2.6$ & $\mathrm{a}$ & $16.4 \pm 8.9$ & $\mathrm{~b}$ \\
Lupanine & $10.8 \pm 13.1$ & $\mathrm{a}$ & $174.5 \pm 87.6$ & $\mathrm{~b}$ \\
\hline
\end{tabular}

Means for the same alkaloid between the locations with different letters are significantly different from each other (alpha $=0.05)$.

northern latitude: 54.071955, eastern longitude: 12.321031). Field experiments were conducted in a randomized block design with four replications with a plot size of $9.6 \mathrm{~m}^{2}$. The alkaloid content in these trials was analysed on a mixed sample of each cultivar. In 2010 the variety Boruta and the variety Haags Blaue as well as six newly developed breeding lines (51-56) of the Saatzucht Steinach were grown in field experiments in fourfold replications in $4.2 \mathrm{~m}^{2}$ plots at different soils at Gründl (Bavaria, northern latitude: 48.519305, eastern longitude: 11.816175) and Bornhof (Mecklenburg-Western Pomerania, northern latitude: 53.477371, eastern longitude: 12.911754) under conventional growing conditions. In this experiment the alkaloid content was measured separately for each plot. In Table 1 the characteristics of the locations are given.

2.2. Determination of the Alkaloid Content. Grain samples of about $250 \mathrm{~g}$ were randomly taken and grounded as described by [14]. All wholemeal samples revealed a dry matter content of about $90 \%$ and were stored at $20^{\circ} \mathrm{C}$ until analysis. The subsequent alkaloid analysis in lupin whole meal flour was carried out according to [14-16]. Main alkaloids were calculated as the sum of alkaloids shown in Figure 1. The main alkaloids in narrow-leafed lupins are angustifoline, isolupanine, lupanine, and 13-hydroxylupanine.

The determination of the alkaloid content was performed twice per sample with a coefficient of variation lower than $4 \%$.

2.3. Statistical Analysis. To assess the effects of the location on the alkaloid content, a generalized linear model for the analysis of variance (ANOVA) was applied, using the GLM procedure of the software package SAS (version 9.3) followed by a Tukey test $(\alpha=0.05)$ for comparing the means. The two datasets were analysed separately.

\section{Results and Discussion}

The alkaloid content in sweet narrow-leaf lupin cultivars is in general very low. Already Sengbusch [17] suggested to call lupins alkaloid-poor $(0.05 \%$ alkaloids in seeds $)$ or alkaloid-free $(0.025 \%$ alkaloids in seeds). Nevertheless, the seed alkaloid content of sweet lupins is influenced by different environmental factors such as fertilizers [1822], ambient temperature during initiation of flowering up to pod ripening [14], and drought stress [23]. In 2004

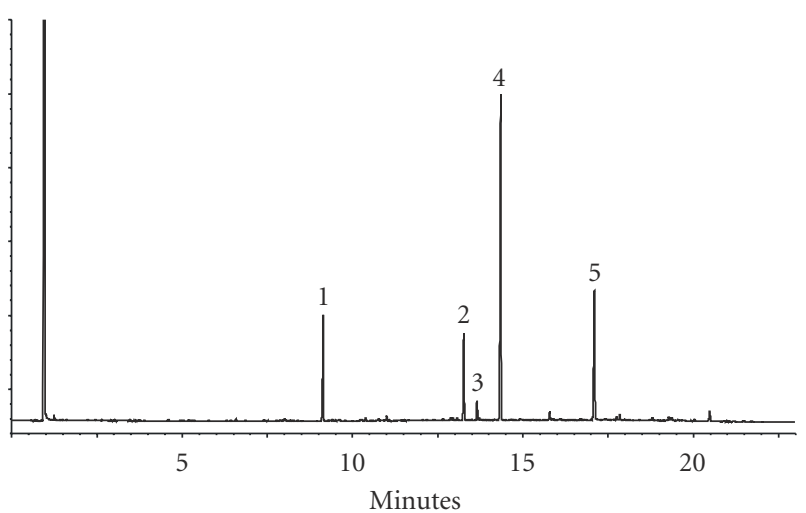

FIGURE 1: Gas chromatogram for different alkaloids (1 ISTDCaffeine, 2 Angustifoline, 3 Iso-Lupanine, 4 Lupanine, 5 13Hydroxy-Lupanine) present in cultivar Haags Blaue grown at Bornhof.

and 2005, the mean daily temperature at the beginning of flowering until harvest in August was very similar [14]. The experiments were also carried out under uniform agronomic management (fertilizer, herbicides, etc.), so that the abiotic stress factors temperature, drought, and nutrient deficiency as well as mechanical damage can be neglected. In 2004 at Bogen the main alkaloid content of the cultivars tested ranged between $11.2 \mu \mathrm{g} / \mathrm{g}$ for the cultivar Vitabor and $92.5 \mu \mathrm{g} / \mathrm{g}$ for the cultivar Sonet and $90.1 \mu \mathrm{g} / \mathrm{g}$ for Bolivio. At Gross Luesewitz the alkaloid content ranged between $60.3 \mu \mathrm{g} / \mathrm{g}$ for cultivar Vitabor and $521.2 \mu \mathrm{g} / \mathrm{g}$ for cultivar Bolivio. The alkaloid content of all varieties tested is shown in Table 2. In 2005, as expected, the lowest alkaloid content was also found in the cultivar Vitabor (Bogen $3.5 \mu \mathrm{g} / \mathrm{g}$ and Gross Luesewitz $64.8 \mu \mathrm{g} / \mathrm{g}$ ) and the highest content in Sonet (Bogen 131.6 $\mu \mathrm{g} / \mathrm{g}$ and Gross Luesewitz $567.0 \mu \mathrm{g} / \mathrm{g}$ ).

Out of all alkaloids analyzed the lupanine content shows the largest increase with decreasing soil $\mathrm{pH}$. Christiansen et al. [23] reported that drought stress during the vegetative phase reduces mostly the concentration of lupanine, 13hydroxylupanine, and angustifoline, whereas isolupanine is affected to a much smaller extent.

The differences in the alkaloid content between the locations in Mecklenburg-Western Pomerania and Bavaria are significant (Table 3 ).

Figure 2 clearly demonstrates that the alkaloid production is significantly higher when lupins are cultivated at a lower $\mathrm{pH}$ (mean value of two years is shown). However, also clear differences are observed between cultivars opening the opportunity to breed cultivars with low alkaloid content under low $\mathrm{pH}$ conditions, for example, Vitabor.

In 2010 also two cultivars and six newly developed breeding lines of Lupinus angustifolius were analyzed concerning the alkaloid content at locations with different soil $\mathrm{pH}$. At Gründl ( $\mathrm{pH}=6.7)$ the total alkaloid content ranged between $0.0166 \%$ and $0.1293 \%$ while at Bornhof $(\mathrm{pH}=5.3)$ the alkaloid content was in general higher and ranged between $0.029 \%$ and $0.1810 \%$ (Figure 3 ). The variety Boruta and 
TABLE 4: Mean alkaloid content estimated on soil with $\mathrm{pH}=5.8$ and $\mathrm{pH}=7.2$ observed in cultivars of Lupinus angustifolius at different locations (2004 and 2005, $n=22$ ).

\begin{tabular}{lcc}
\hline Location & 2004 & Main alkaloid content [\%] \\
\hline Mecklenburg-Western Pomerania $(\mathrm{pH}=5.8)$ & 0.0330 & 0.0339 \\
Bavaria $(\mathrm{pH}=7.2)$ & 0.0043 & 0.0029 \\
\hline Least significant difference (Tukey, $\alpha=0.05)$ & 0.0084 & 0.01 \\
\hline
\end{tabular}

TABLE 5: Mean alkaloid content estimated on soil with $\mathrm{pH}=5.3$ and $\mathrm{pH}=6.7$ observed in actual varieties and breeding lines of Lupinus angustifolius $L$. at different locations $(2010, n=32)$.

\begin{tabular}{lc}
\hline Location & Alkaloid content $[\%]$ \\
\hline Mecklenburg-Western Pomerania $(\mathrm{pH}=5.3)$ & 0.0687 \\
Bavaria $(\mathrm{pH}=6.7)$ & 0.0355 \\
\hline Least significant difference (Tukey, $\alpha=0.05)$ & 0.0081 \\
\hline
\end{tabular}

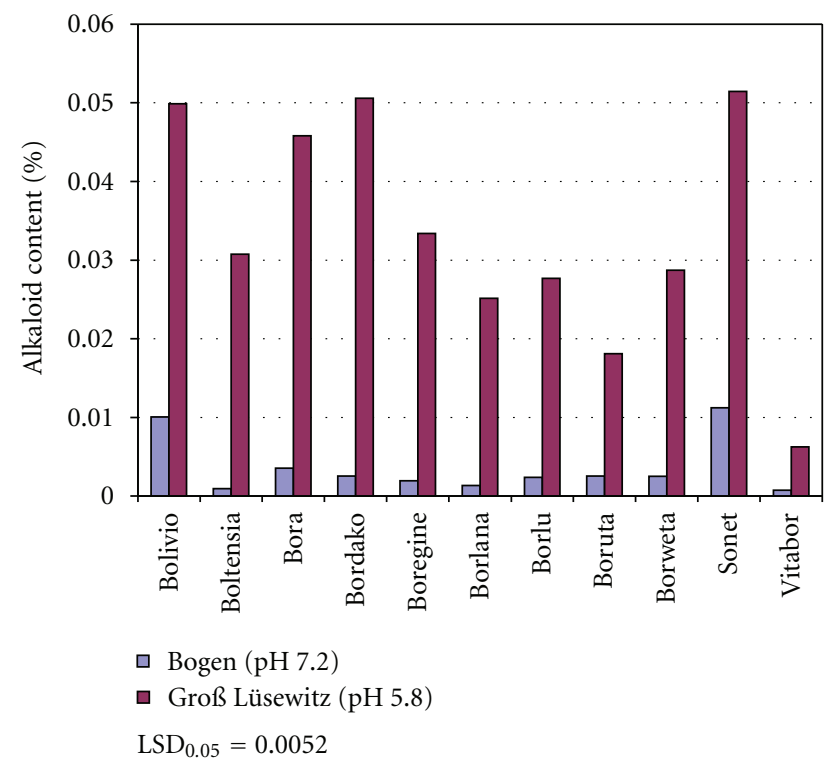

Figure 2: Influence of the soil $\mathrm{pH}$ on the main alkaloid content of Lupinus angustifolius (mean of 2004 and 2005).

two new breeding lines revealed the lowest alkaloid content (Figure 3).

Concerning the average main alkaloid content in cultivars and breeding lines significant differences between locations were observed in 2010 (Table 5) as it was previously observed in 2004 and 2005 (Table 4). In Germany, there is no law concerning the upper threshold of alkaloids in lupins for animal feed and human nutrition, but in general the upper threshold for use in animal and human nutrition is $0.05 \%$ and $0.02 \%$, respectively. In 2010 this threshold has been exceeded in general at the soil with the lower pH (Mecklenburg-Western Pomerania) and also by some cultivars in 2004/2005.

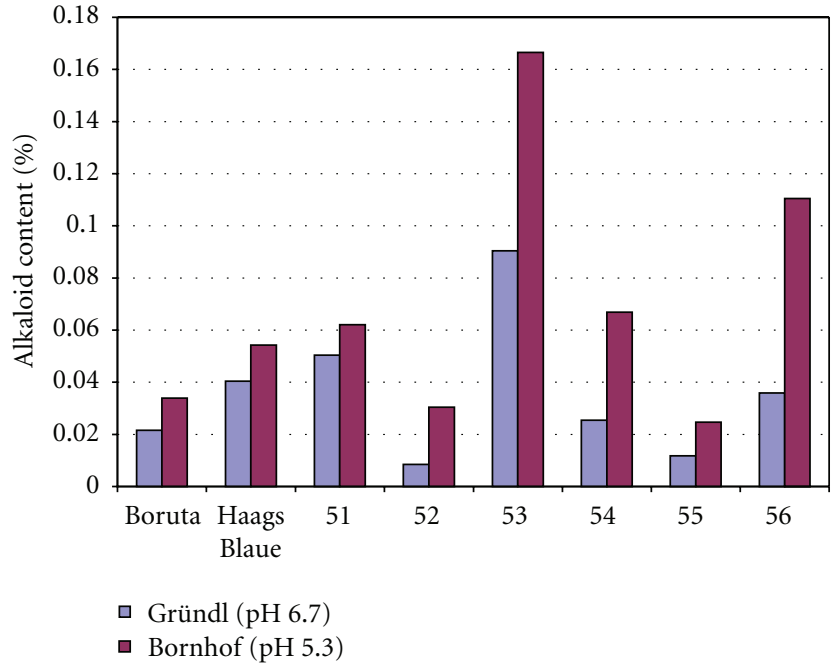

Figure 3: Influence of the soil $\mathrm{pH}$ on the main alkaloid content of Lupinus angustifolius cultivars and breeding lines (2010).

For lupin cultivation a rather low soil $\mathrm{pH}(\mathrm{pH}=5.0-6.8)$ is recommended [5]. Jansen et al. [16] reported that the grain yield at $\mathrm{pH}=7.2$ is lower than at $\mathrm{pH}=5.8$. On the other hand the alkaloid content of Lupinus angustifolius decreases significantly at a higher $\mathrm{pH}$ (Figures 2 and 3 ). Therefore, for a high yield combined with low alkaloid content, the soil $\mathrm{pH}$ is of prime importance, although it has to be taken into account that also additional environmental factors, for example, drought stress, fertilization, and temperature, can have an adverse effect on the alkaloid content in lupin seeds. Yaber Grass and Leicach [24] noted that a significant increase in the total alkaloid content was observed from samples of Senecio grisebachii growing in highly deteriorated soil compared to those from samples grown in less deteriorated ones.

The results presented show that additional breeding efforts are needed to achieve low alkaloid content also under low soil $\mathrm{pH}$. As shown in Figures 2 and 3 genetic variation concerning this trait is present in cultivars and new breeding lines which could be exploited in the future.

\section{Acknowledgments}

The authors thank Ch. Peters and M. Jennerjahn for technical assistance. This work was supported by the BMBF with the Project no. 03WKBV01B and BLE with the Project no. $03 \mathrm{OE} 355$. 


\section{References}

[1] W. Hondelmann, "Die Lupine-Geschichte und Evolution einer Kulturpflanze," Landbauforschung Völkenrode, vol. 162, pp. 10-18, 1996.

[2] R. von Sengbusch, "Bitterstoffarme Lupinen III," Der Züchter Zeitschrift für Theoretische und Angewandte Genetik, vol. 10, no. 4, pp. 91-95, 1938.

[3] 2011, http://www.biosicherheit.de/lexikon/1277.abiotischestressfaktoren.html.

[4] C. Tang, B. J. Buirchell, N. E. Longnecker, and A. D. Robson, "Variation in the growth of lupin species and genotypes on alkaline soil," Plant and Soil, vol. 155-156, no. 1, pp. 513-516, 1993.

[5] U. Schmiechen, Anbauratgeber Blaue Süßlupine, 2011, http:// www.ufop.de/files/9113/4080/9714/PI_Blaue_Suesslupine_ 240611.pdf.

[6] J. S. Gladstones, "Lupins as crop plants," Field Crop Abstracts, vol. 23, pp. 123-148, 1970.

[7] G. Jansen, H. U. Jürgens, and W. Flamme, Züchterische Bearbeitung von Süßlupinen für den ökologischen LandbauQualitätsuntersuchungen im Hinblick auf Futtereignung, Bericht orgprints, 2006, http://orgprints.org/11087/1/11087-03 OE355-jki-jansen-2006-suesslupinen.pdf.

[8] G. Jansen, F. Eickmeyer, and V. Michel, "Einfluss von Kalkung und $\mathrm{pH}$-Wert im Boden auf Kornertrag und Eiweißgehalt von Lupinus angustifolius L," Journal für Kulturpflanzen, vol. 62, no. 10, pp. 367-375, 2010.

[9] X. Yan, S. Wu, Y. Wang, X. Shang, and S. Dai, "Soil nutrient factors related to salidroside production of Rhodiola sachalinensis distributed in Chang Bai Mountain," Environmental and Experimental Botany, vol. 52, no. 3, pp. 267-276, 2004.

[10] A. G. Medentsev, A. Y. Arinbasarova, and V. K. Akimenko, "Biosynthesis of naphthoquinone pigments by fungi of the genus Fusarium," Applied Biochemistry and Microbiology, vol. 41, no. 5, pp. 503-507, 2005.

[11] P. Babula, R. Mikelova, V. Adam, R. Kizek, L. Havel, and Z. Sladky, "Using of liquid chromatography coupled with diode array detector for determination of naphthoquinones in plants and for investigation of influence of $\mathrm{pH}$ of cultivation medium on content of plumbagin in Dionaea muscipula," Journal of Chromatography B, vol. 842, no. 1, pp. 28-35, 2006.

[12] R. Endres, "Influence of culture conditions on secondary metabolite accumulation. Plant cell biotechnology," in Plant Cell Biotechnology, pp. 187-242, Springer, New York, NY, USA, 1994.

[13] A. K. Klamroth and R. Dieterich, "Genotyp-UmweltWechselwirkung bei der Blauen Süßlupine am Beispiel ausgewählter Ertragsparameter," in Tagungsband 61. Tagung der Vereinigung der Pflanzenzüchter und Saatgutkaufleute Österreichs, pp. 101-104, Gumpenstein, Austria, 2010.

[14] M. Wink, C. Meissner, and L. Witte, "Patterns of quinolizidine alkaloids in 56 species of the genus Lupinus," Phytochemistry, vol. 38, no. 1, pp. 139-153, 1995.

[15] K. Bermúdez Torres, N. Robledo Quintos, L. L. Barrera Necha, and M. Wink, "Alkaloid profile of leaves and seeds of Lupinus hintonii C. P. Smith," Zeitschrift fur Naturforschung C, vol. 57, no. 3-4, pp. 243-247, 2002.

[16] G. Jansen, H. U. Jürgens, and F. Ordon, "Effects of temperature on the alkaloid content of seeds of Lupinus angustifolius cultivars," Journal of Agronomy and Crop Science, vol. 195, no. 3, pp. 172-177, 2009.
[17] R. von Sengbusch, "Süßlupinen und Öllupinen. Teil III. Die Entstehungsgeschichte einiger neuer Kulturpflanzen," Landwirtschaftliches Jahrbuch, vol. 91, pp. 793-880, 1942.

[18] P. Barlóg, "Effect of magnesium and nitrogenous fertilisers on the growth and alkaloid content in Lupinus angustifolius L," Australian Journal of Agricultural Research, vol. 53, no. 6, pp. 671-676, 2002.

[19] D. Ciesiołka, M. Muzquiz, C. Burbano et al., "An effect of various nitrogen forms used as fertilizer on Lupinus albus L. yield and protein, alkaloid and $\alpha$-galactosides content," Journal of Agronomy and Crop Science, vol. 191, no. 6, pp. 458-463, 2005.

[20] P. Gremigni, M. T. F. Wong, N. K. Edwards, D. Harris, and J. Hamblin, "Potassium nutrition effects on seed alkaloid concentrations, yield and mineral content of lupins (Lupinus angustifolius)," Plant and Soil, vol. 234, no. 1, pp. 131-142, 2001.

[21] P. Gremigni, J. Hamblin, and D. Harris, "Genotype x Environment Interactions and Lupin Alkaloids," in Proceedings of the 9th International Lupin Conference, 2002.

[22] P. Gremigni, J. Hamblin, D. Harris, and W. A. Cowling, "The interaction of phosphorus and potassium with seed alkaloid concentrations, yield and mineral content in narrow-leafed lupin (Lupinus angustifolius L.)," Plant and Soil, vol. 253, no. 2, pp. 413-427, 2003.

[23] J. L. Christiansen, B. Joørnsgård, S. Buskov, and C. E. Olsen, "Effect of drought stress on content and composition of seed alkaloids in narrow-leafed lupin, Lupinus angustifolius L," European Journal of Agronomy, vol. 7, no. 4, pp. 307-314, 1997.

[24] M. A. Yaber Grass and S. R. Leicach, "Changes in Senecio grisebachii pyrrolizidine alkaloids abundances and profiles as response to soil quality," Journal of Plant Interactions, vol. 7, no. 2, pp. 175-182, 2011. 


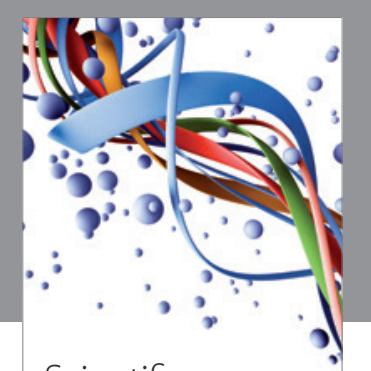

Scientifica
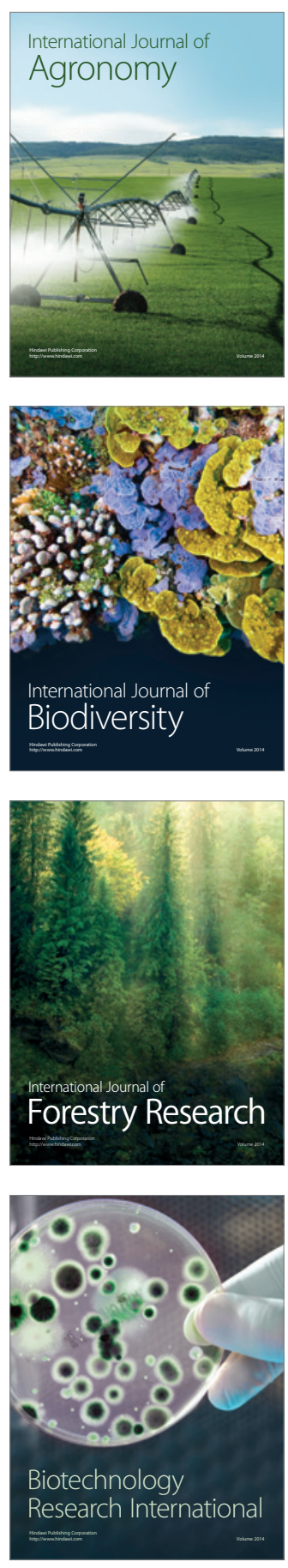
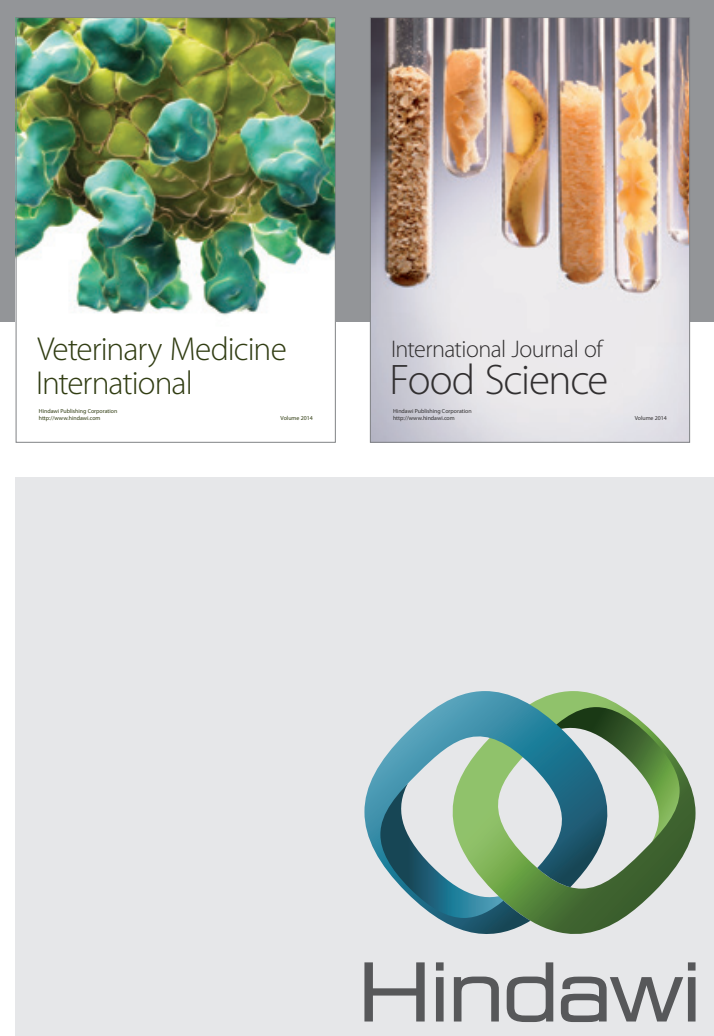

Submit your manuscripts at

http://www.hindawi.com
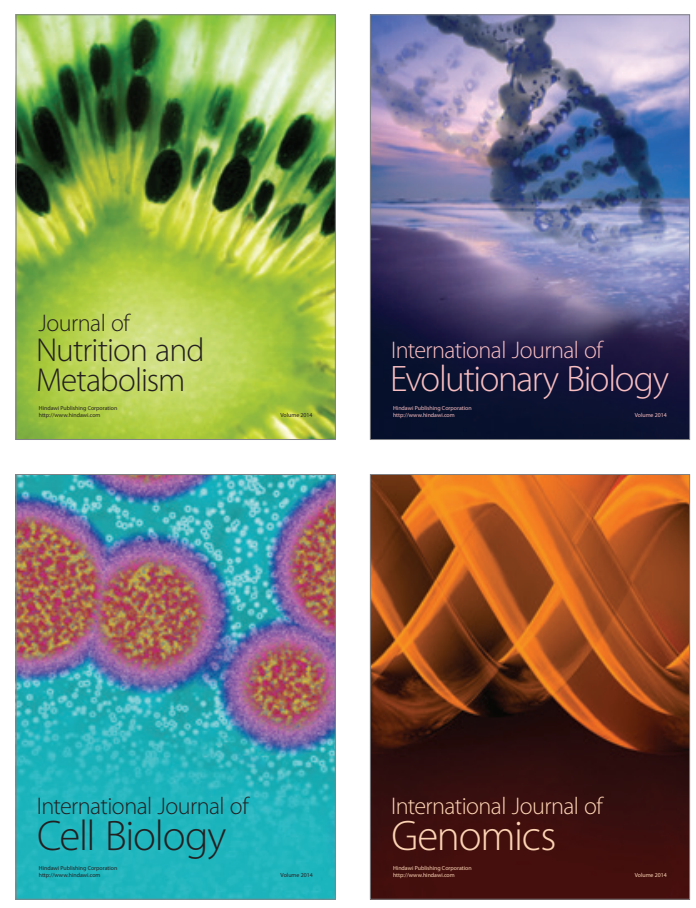
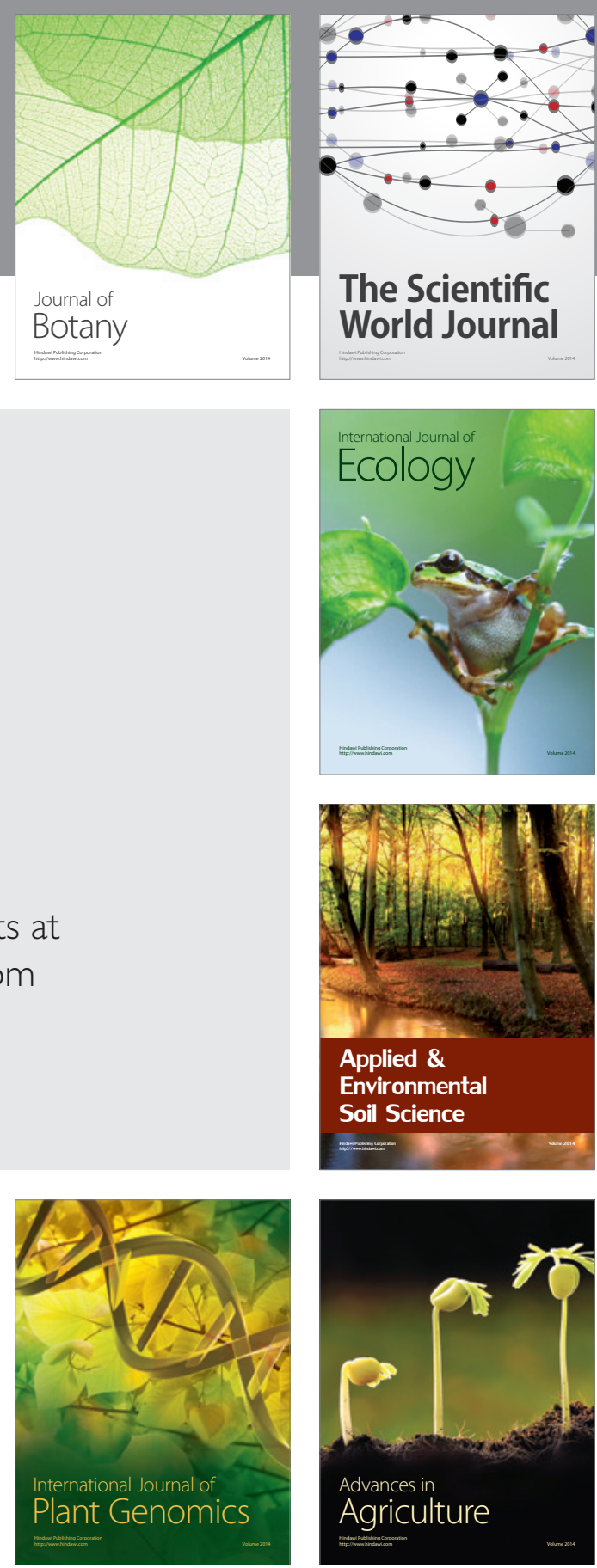

The Scientific World Journal
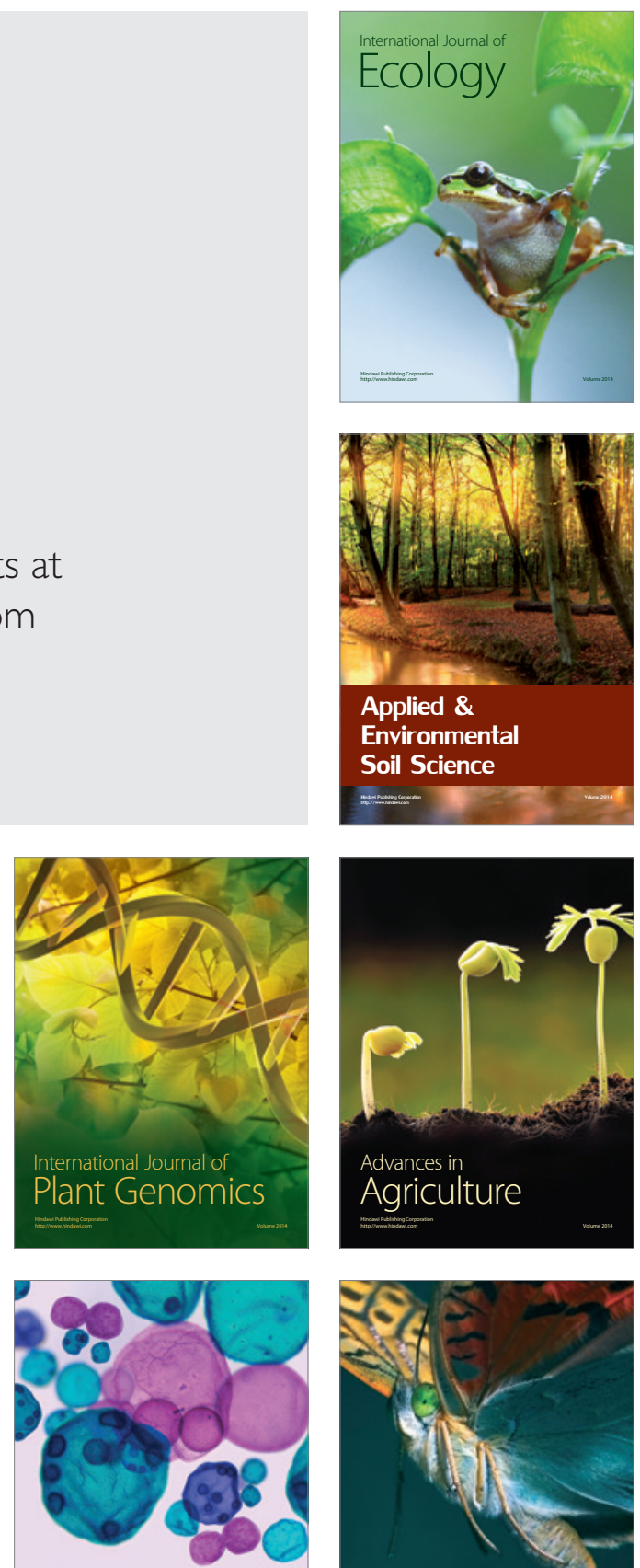

International Journal of Microbiology

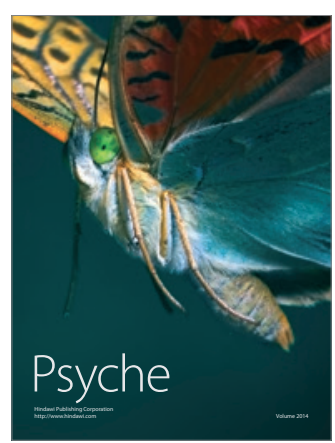

